\title{
変敗油の調理に及ぼす影響について（第16報） \\ Influence of Rancid Oil on the Cooking (Part 16)
}

食塩処理による油揚げ鯨肉の防縮性と消化性について

Effect of Sodium Chloride upon the Digestibility and

Antishrinking of Fried whale Meat

神戸森女子短期大学 (Kobe Mori Women's College)

梶 本 五 郎 (Goroh Kajimoto) 谷 田 博 美 (Hiromi Tanida)

Whale meat were fried at $170^{\circ} \mathrm{C}$ for 4 minutes with soybean oil that digestion of $1 \mathrm{hr}$ in $10 \%$ Sodium chloride, Sugar and Vinegar solution, experiment has contraction and digestibility of these materials.

The results obtained in above test with treated Sodium chlorid was found to be more than antishrinking that of Sugar and Vinegar solution, there was a prononced high in the digestibility of fried whale meat as the concentration of Sodium chloride.

Also the influence of digested time and concentrated of Sodium chloride for therse contraction and digestibility changes was observed.

緒言 牛肉, 豚肉, 倞肉等を焼いたり, 煮たり, 油揚げを行うと肉色の変化, 重量及び容積の縮少と一段と 香気及び風味をますもので, 乙れらの原因については色々と考劣られているが, 肉の防縮它目的にした実験報 告を殆えどみないのである。

そこで今回, 肉の縮少防止を目的に実験を進め, 油揚げ鯨肉の防縮には食塩溶液の浸漬が最も效果があり, 且つたえ白質の消化性においても食塩の影響が殁えどないといつた結果を得たので報告する。

\section{実験の部}

1. 試料及び試料の調製

揚げ油として大豆油を選び，鯨肉は市販の冷凍赤鯨肉を使用し， $10 \mathrm{~cm}^{2}$, 厚さ $1 \mathrm{~cm}$ ののを揚げた。

食塩, 砂糖, 食酢及び醬油 (キッコマン) はいずれも市販品を用い, 10 \%濃度の食塩, 砂糖, 食酢, 醬油溶 液を調製し, 鯨肉を 1 時間浸漬した。

又, 食塩は $1 \%, 5 \%, 10 \%$ 溶液を作り, 鯨肉を 1 時間浸漬し，10\%食塩溶液については，浸漬時間をそれ ぞれ20分, 60 分, 180 分とした。

以上, 各溶液に浸漬した鯨肉を取出し, 30分後, 油揚げを行なつた。

2. 実験方法

i) 揚げ方

21 入の鉄鍋中に大豆油を 11 いれ, $170^{\circ} \mathrm{C}$ に浸漬処理した鯨肉を 4 分間揚げた。なお 4 分間は食事に適 した時間であつた。 
ii）揚げ肉の防縮性について

油揚げした鯨肉の面積を測定し，油揚げ前の面積に対する収縮率を求めた。即ち下式のとおりである。 $\frac{\text { 油揚げ前の鯨肉の面積一油揚げ後の鯨肉の面積 }}{\text { 油揚げ前の鯨肉の面積 }} \times 100=$ 収縮率 $(\%)$

iii) 消化性について

油揚げした鯨肉を直ちにソックスレー抽出器にて 1 時間エーテルで脱脂し, 脱脂鯨肉について大高の方法に 準じ消化性を求めた。即ち, 乳銪にてすりつぶした鯨肉を $1 \mathrm{~g}$ ずつとり, $\mathrm{pH} 8.6$ にし, 次いで $0.5 \mathrm{~g}$ のパ ンクレアチンを加え $38^{\circ} \mathrm{C}$ にて24時間消化させ，消化の程度を比較するのに Pope-Stevens の加銅法により アミノ態窒素量を求め, 消化性を比較した。

\section{$\frac{\text { アミノ態窒素量 }}{\text { 全音素量 }} \times 100=$ 消化性 $(\%)$}

なお，全窒素量及びアミノ態空素量は，乾燥重量に対する百分率で表わした。 消化率としての比較は, 前穾験では, 消化性も消化率も同傾向にあつたので, 今回は消化性のみにて評価した。

\section{実験結果及び考察}

1. 食塩, 砂糖, 食酢溶液浸漬と油揚げ鯨肉の防縮性について

広く使用されている食塩, 砂糖, 食酢の $10 \%$ 溶液に鯨肉を 1 時間浸漬し, 浸漬処理した鯨肉を油揚げし, そ

第 1 表 $10 \%$ 食塩, 砂糖, 食酢溶液浸漬と油揚げ鯨肉の収 縮率について（収縮率％)

\begin{tabular}{|c|c|c|c|c|}
\hline $\begin{array}{r}\text { 処理溶 } \\
\text { 測定数 }\end{array}$ & 無処理 & $10 \%$ 食塩 & $10 \%$ 砂糖 & $10 \%$ 食酢 \\
\hline 1 & $33.0 \%$ & $26.1 \%$ & $35.0 \%$ & $33.3 \%$ \\
2 & 30.8 & 29.3 & 31.7 & 31.0 \\
3 & 32.3 & 18.0 & 29.6 & 26.0 \\
平 均 & $32.0 \%$ & $24.5 \%$ & $32.1 \%$ & $30.1 \%$ \\
\hline
\end{tabular}

の収縮率を求めた。 その結果は第 1 表のとおりである。 収縮率は, 毎実験共凡之同一の傾向にあつた ので, 3 回の測定值を平均し求めた。処理溶液 の内，食塩が最も収㴼率が小さい。即ち防縮性 があり，砂糖，食酢処理は防縮性がなかつた。 加熱による肉組織, たえ白質の凝固現象にと もなう収縮で食塩溶液の浸漬では Sebelian

報告のごとく，たく白質の凝固温度を高めた結果無処理鯨肉に比べ収縮が少ないと考光ら机る。砂糖も Haurowitz の報告から考光ると熱凝固性を阻止し，防縮性をあらわすものと思われたが，実験結果では防縮： 効果がなかつた。したがつて食塩と砂糖の両物質で:, 物理的な現象以外に, 他に相違する原因があると推察. される。

第 2 表 食塩濃度と油揚げ鯨肉の収縮率について (収縮率)

\begin{tabular}{|c|l|l|l|l|}
\hline $\begin{array}{r}\text { 食塩濃 } \\
\text { 測定数 }\end{array}$ & $0 \%$ & $1 \%$ & $5 \%$ & $10 \%$ \\
\hline 1 & 22.2 & 27.8 & 22.8 & 19.5 \\
2 & 36.8 & 34.5 & 28.8 & 20.8 \\
3 & 29.5 & 22.9 & 25.4 & 27.6 \\
4 & 38.4 & 38.2 & 22.5 & 26.2 \\
5 & 31.8 & 30.0 & 11.4 & 17.4 \\
6 & 38.6 & 32.7 & 24.0 & 20.6 \\
平 均 & $32.9 \%$ & $31.0 \%$ & $23.5 \%$ & $23.0 \%$ \\
\hline
\end{tabular}

2. 食塩濃度と油揚げ鯨肉の防縮性及び消化 性について

揚げ鯨肉の収縮率を防いだ食塩について, 次 いで食塩濃度を $1 \%$ ，5％，10\%とし，鯨肉を 1 時間浸漬したものについて, 前実験同様, 油” 揚げ鯨肉の防縮性を求めた。

その結果は第 2 表のとおりである。

$1 \%$ 食塩溶液浸漬では, 僅かに防縮性を示乙

$5 \%$ 食塩溶液及びそれ以上の濃度では収縮を大 いに防止した。 
以上のごとく収縮を防止した鯨肉の消化性が 如何なるものかを検討した。

その結果は第 $3 \sim 4$ 表のとおりで，4 表は消 化性を一括して表示した。

消化性は, 食塩濃度 $5 \%$ 溶液までは, コント ロールとかわらず，10％溶液に浸漬した油揚げ

鯨肉法しろ消化性がよくなつた。 高は生鶏肉について詳細な実験を行ない, 食塩 濃度が濃くなる程, 消化性は低下すると報告し ている。

著者らの実験では, 食塩以外に油揚げ加熱の

影響が考えられ，第13報にて報告したごとく，

たえ白変性の度合の相違により消化性も変化し たものと思われる。

3. 食塩溶液の浸漬時間と油揚げ鯨肉の防縮 性及び消化性について

食塩濃度 $10 \%$ 溶液が防縮性及び消化性共にす ぐれていたので, $10 \%$ 溶液を使用し, 觡肉の浸 漬時間と油揚げ後の防縮性及び消化性を調 ゙゙ た。それらの結果は第 5 〜表のとおりであ る。

浸漬時間の長い程, 収縮率沙ない。即ち鯨 肉えの食塩の浸透量が増加したためで, 鯨肉光 の浸透量は材料重量に対し, 20 分浸漬で $0.8 \%$, 60分で $1.0 \%, 180$ 分で $1.1 \%$ であつた。

消化性核浸漬時間とは殆えど関係なく, 180 分浸漬で僅汃増加した。

4. 醬油えの浸漬時間と油揚け鮒肉の防縮性 及び消化性について 第 5 表 食塩溶液浸漬時間と油揚げ倞肉の収縮率に ついて (収縮率\%)

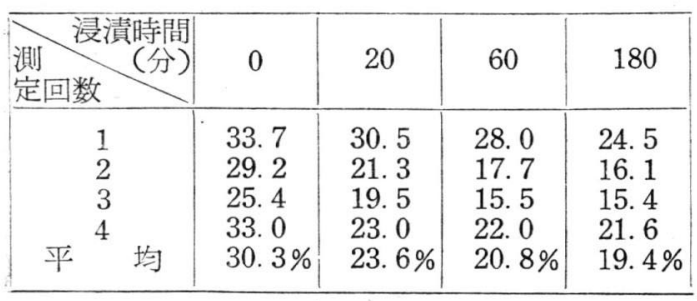

第 3 表 食塩濃度と油揚げ鯨肉の消化性について 1 回

\begin{tabular}{|c|c|c|c|c|}
\hline 則定值 & 0 & $1 \%$ & $5 \%$ & $10 \%$ \\
\hline 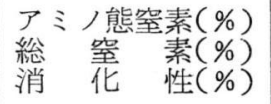 & $\begin{array}{r}\text { 5. } 0 \\
\text { 13. } 3 \\
\text { 37. } 5\end{array}$ & $\begin{array}{r}4.9 \\
12.5 \\
39.2\end{array}$ & $\begin{array}{r}4.7 \\
13.3 \\
35.3\end{array}$ & $\begin{array}{r}5.4 \\
11.2 \\
48.1\end{array}$ \\
\hline
\end{tabular}

2 回

\begin{tabular}{|c|c|c|c|c|}
\hline アミノ態窒素(\%) & 5.1 & 5. 4 & 5.9 & 5.0 \\
\hline 総窒 素 $(\%$ & 11. 8 & 12. 7 & 12. 2 & 9.5 \\
\hline 消 化 性(\%) & 43.0 & 42.5 & 48.6 & 53.0 \\
\hline
\end{tabular}

3 回

\begin{tabular}{|c|c|c|c|c|}
\hline 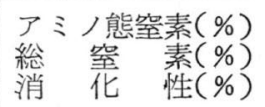 & $\begin{array}{r}5.5 \\
14.9 \\
37.0\end{array}$ & $\begin{array}{r}5.0 \\
14.3 \\
35.0\end{array}$ & $\begin{array}{r}4.7 \\
13.0 \\
36.2\end{array}$ & $\begin{array}{r}4.9 \\
12.2 \\
40.1\end{array}$ \\
\hline
\end{tabular}

4 回

\begin{tabular}{|c|c|c|c|c|}
\hline 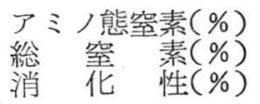 & $\begin{array}{r}5.3 \\
14.0 \\
37.8\end{array}$ & $\begin{array}{r}5.6 \\
14.2 \\
39.4\end{array}$ & $\begin{array}{r}5.1 \\
14.1 \\
36.1\end{array}$ & $\begin{array}{r}5.2 \\
13.5 \\
38.4\end{array}$ \\
\hline \multicolumn{5}{|c|}{5 回 } \\
\hline $\begin{array}{l}\text { アミノ態窒素 }(\%) \\
\text { 総 室 }(\%) \\
\text { 消 珄 }(\%)\end{array}$ & $\begin{array}{r}4.8 \\
12.6 \\
38.0\end{array}$ & $\begin{array}{r}4.6 \\
12.7 \\
36.2\end{array}$ & $\begin{array}{r}4.6 \\
12.7 \\
36.2\end{array}$ & $\begin{array}{r}4.6 \\
11.7 \\
39.3\end{array}$ \\
\hline
\end{tabular}

6 回

\begin{tabular}{|c|c|c|c|c|}
\hline $\begin{array}{c}\text { ア 態窒素( }(\%) \\
\text { 総 } \\
\text { 窒 } \\
\text { 消 }\end{array}$ & $\begin{array}{r}5.2 \\
13.6 \\
38.2\end{array}$ & $\begin{array}{r}5.1 \\
13.5 \\
37.7\end{array}$ & $\begin{array}{r}5.1 \\
12.2 \\
41.7\end{array}$ & $\begin{array}{r}5.5 \\
11.4 \\
48.2\end{array}$ \\
\hline
\end{tabular}

第 4 表 食塩濃度と油揚げ鯨肉の消化性について

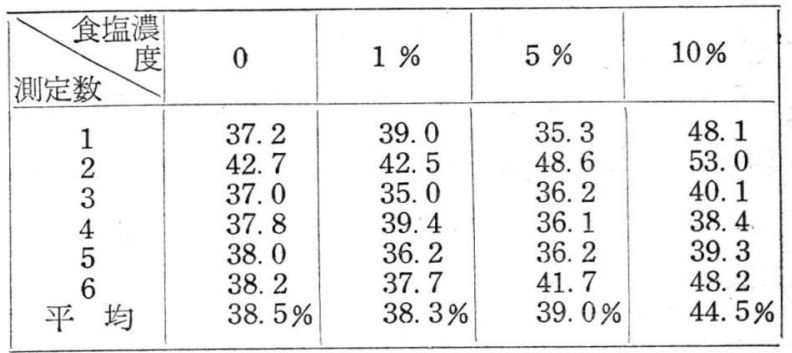

第 6 表 食塩溶液の浸清時間と油揚状鯨肉の消化性 について

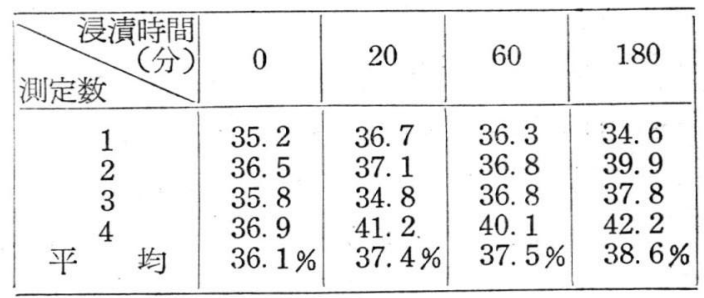


油揚げ鯨肉の収縮防止には食塩水の浸漬が望ましいととを知り，且つ塩味をおびた食味が得られた。更に美 味を増すため甥油溶液に浸漬し, 油揚げ鯨肉の防縮性, 消化性及び食味を観察した。

醬油濃度注予め $10 \%$ 溶液（食塩濃度として $1.8 \%$ に当る）とし，鯨肉を 1 時間及び 12 時間浸漬した。 なお, 鯨肉中に吸収される醬油のたえ白質量は, 食塩の吸収量から計算し求め, 消化性を求める場合は, 全 室素量より吸収された窒素量を引き, 吸収された醬油中のアミノ態空素量は浸漬処理後, 一部分を切取り, 水 洗によりアミノ態窒素を溶出させ, 溶出したアミノ態窒素を加銅法により求め, 消化試験後のアミノ態窒素量 より, 差引き消化性を求めた。

それらの結果注第 7 ～表のとおりである。

第 7 表 醬油への浸漬時間と油揚げ鯨肉の収縮率に ついて (収縮率\%)

\begin{tabular}{|c|l|l|l|}
\hline $\begin{array}{r}\text { 浸漬時間 } \\
\text { 測 定 数 }\end{array}$ & 0 & 1 & 12 \\
\hline 1 & 35.0 & 26.8 & 22.0 \\
2 & 31.9 & 29.4 & 25.9 \\
3 & 37.5 & 37.0 & 31.0 \\
4 & 38.0 & 34.5 & 29.0 \\
平 均 & $35.6 \%$ & $31.9 \%$ & $27.0 \%$ \\
\hline
\end{tabular}

第 8 表 醬油への浸漬時間と油揚げ鯨肉の消化性に: ついて

\begin{tabular}{|c|c|c|c|}
\hline $\begin{array}{r}\text { 浸漬時間 } \\
\text { 測 定 数 }\end{array}$ & 0 & 1 & 12 \\
\hline 1 & 36.5 & 34.2 & 38.8 \\
2 & 34.7 & 32.1 & 34.8 \\
3 & 35.7 & 33.0 & 38.4 \\
4 & 38.6 & 31.4 & 38.6 \\
平 均 & 36.4 & 32.7 & 37.6 \\
\hline
\end{tabular}

醬油の場合も食塩と同様, 油揚げ鯨肉の収縮を防ぎ, 消化性は 1 時間浸漬の場合には劣つた。恐らく鯨肉に 吸収された醬油たん白質の求め方の誤差によつたとも考えられ，更にこの点については検討したい。 食味の点では，それ灻れ個人差があり，著者は旨しく思つた。

要 約

1. 食塩, 砂糖及び食酢の $10 \%$ 溶液に冷凍赤鯨肉 $\left(10 \mathrm{~cm}^{2}\right.$, 厚さ $\left.1 \mathrm{~cm}\right)$ をそれぞれ 1 時間浸漬し, 浸漬後: 21 入鉄鍋中に 11 の大豆油を入れ, $170^{\circ} \mathrm{C} て ゙ 4$ 分間揚げ, 面積収縮率を求めてみると, 無処理油揚げ倞肉 で $32.0 \%$, 食塩浸漬で $24.5 \%$, 砂糖浸漬で $32.1 \%$, 食酢で $30.1 \%$ となり, 食塩浸漬が最も防縮性效果があ. つた。

2. $1 ， 5 ， 10 \%$ 食塩溶液にそれぞれ鯨肉を 1 時間浸漬し, 油揚げ鯨肉の収縮率及び消化性を調べた結果, $5 \%$ 溶液以上では防縮効果は大きく, 消化性は $10 \%$ 溶液浸漬のものが最もすぐれていた。

3. $10 \%$ 食塩溶液に鯨肉を 20 分， 60 分， 180 分間ずつ浸漬し，油揚げ後の収縮率及び消化性をみると，浸漬 時間の長い程，防縮性にとみ，消化性は浸漬時間とは関係なく凡そ一定であつた。

4. $10 \%$ 醬油溶液（食塩濃度として $1.8 \%$ ）に鯨肉を 1 時間及び 12 時間浸漬し，同様油揚げ鯨肉の収縮率及 び消化性を調べると，浸漬時間の長い程，防縮性がよくなり，消化性は 1 時間浸漬が最もわるかつた。

文献

1 ) 大高, 黒沢 : 栄養と食糧, 13, 372 (1961)

2 ) 梶本: 栄養と食糧, 投稿受理

3 ) Sebelien：たん白質化学, 共立出版株式会社

4) F. Haurowitz: The Chemistry and Biology of Proteine (1955)

（受付：昭和 37 年 2 月 19 日） 